\title{
Errata
}

Compositional Relations among Hornblende and Pyroxenes in Basic Granulites and an Application to the Origin of Garnets

S. K. Sen

Contr. Mineral. and Petrol. 38, 299—306 (1973)

The caption for Fig. 3 should read

" $K_{D}^{1}-K_{D}^{2}$ plot for the Quairading samples"

instead of

" $K_{D}^{1}-K_{D}^{2}$ plot for the Mecklenburg samples".

\section{Bildungsbedingungen von Al-Fe(III)-Epidoten}

Paul-Karl Hörmann und Michael Raith

Contr. Mineral. and Petrol. 38, 307-320 (1973)

Die Fußnote 1 auf S. 307 muß lauten:

,1 $\mathrm{Fe}(\mathrm{III}) \mathrm{Al}_{2}-\mathrm{Epidot}=\mathrm{Ca}_{2} \cdot \mathrm{Fe}(\mathrm{III}) \cdot \mathrm{Al}_{2} \cdot\left[\mathrm{O} / \mathrm{OH} / \mathrm{Si}_{2} \mathrm{O}_{7} / \mathrm{SiO}_{4}\right]$. 